\title{
Effects of lead on Epidermal wound Contraction and serum biochemistry in West African dwarf goats
}

\author{
Olaifa Abayomi Kayode ${ }^{1^{*}}$, Adewoye Elsie Olufunke ${ }^{2}$, Akpan Matthew Obot ${ }^{3}$ \\ ${ }_{1}$ Department of Veterinary Surgery and Reproduction, University of Ibadan, Nigeria. \\ ${ }^{2}$ Department of Physiology, University of Ibadan, Nigeria. \\ ${ }^{3}$ Department of Veterinary Anatomy, University of Ibadan, Nigeria.
}

Accepted December 16, 2016

\begin{abstract}
Lead contamination through wound could either be environmental and or systemic sources that impair wound healing in animals. The haematological, biochemical changes including thewound healing effects of topical lead poisoning were therefore investigated using ten adult West African dwarf (WAD) goats, randomly divided into two groups of five animals each. The first group served as the control and the second group was treated with lead chloride solution. Wound contraction was compared between the two groups, haematology and serum biochemistry were analysed at each stage of the healing process. The results revealed a delay in wound contraction in the lead treated group. Erythrocyte sedimentation rate, haemoglobin concentration, packed cell volume, albumin, neutrophil count in the lead treated group decreased significantly $(P<0.05)$. Heart rate and temperature increased significantly $(P<0.05, P<0.01)$ in the treated group. This study concluded that epidermal lead exposure impaired wound healing.
\end{abstract}

Keywords: Lead, wound contraction, haematology, biochemistry, West African dwarf goats.

\section{INTRODUCTION}

Lead is a common cause of poisoning in domestic animals throughout the world. It is a heavy, low melting, bluish-gray metal that is ubiquitous in human environment but rarely found naturally as a metal (Siddiqui and Rajurkar, 2008). It is usually found combined with two or more other elements to form lead compounds. Environmental lead $(\mathrm{Pb})$ continues to pose a dangerous and health risk to both humans and animals (Brownie et al., 2009). Lead toxicity is one of the most common poisoning in farm animals (Radostits et al., 2000), and as one of the most hazardous and cumulative environmental pollutants that affect all biological systems through exposure from air, water and food sources (Patra and Swarup, 2000). Lead has been recognized as toxic to wildlife for over a century; and even sub lethal levels may

\footnotetext{
${ }^{*}$ Corresponding author email: akolaifa@yahoo.com
}

cause immunological and neurological problems, biochemical and behavioral changes and physiological disorders that may affect immune response and reproduction (Pain et al., 2009).On a molecular level, proposed mechanisms for toxicity involve fundamental biochemical processes which include lead's ability to inhibit or mimic the actions of calcium (which can affect calcium-dependent or related processes) and to interact with proteins including those with sulfhydryl, amine, phosphate and carboxyl groups (ATSDR, 2005).Lead has been reported to impact a variety of health outcomes including, but not restricted to; neurodevelopment (Bellinger, 2008), cardiovascular disease (Navas-Acien et al., 2007), neurodegenerative diseases and cognitive decline (Weisskopf et al., 2004), immune system impairment (Dietert and Piepenbrink 2006), renal system function (Weaver et al., 2009), and adverse birth outcomes (Andrews et al., 1994).

Wound healing is a complex and dynamic process where by cellular structures and tissue layers are 
reconstructed consisting of four continuous, overlapping, and precisely programmed phases. These phases and their biophysiological functions must occur in the proper sequence, at a specific time, and continue for a specific duration at an optimal intensity (Mathieu et al., 2006). There are many factors that can affect wound healing which interfere with one or more phases in this process, thus causing improper or impaired tissue repair. Goat is an integral part of a traditional crop livestock production (Seyoum, 2002) and is referred to as poor man's cow because they provide milk in enough quantity for household consumption (Odunsi et al., 2005). Goats are also used in ceremonial feasting and payment of social dues (Okunlola, 2000).Goat production contributes to local handcraft industries where its fiber and skins are used extensively. Despite several animal studies on the toxicity of lead, there remains a dearth of information on its effect on wound healing in goats. Therefore, this study was designed to investigate the lead exposure through wound on haematological indices, wound contraction, serum biochemical indices, temperature, respiratory rate and heart rate in West African dwarf goat.

\section{MATERIALS AND METHODS}

Experimental animals: Ten apparently healthy West African dwarf (WAD) goats (age 1-3 years; body weight $15-20 \mathrm{~kg}$ ) were used for the experiment. After the wound creation, the animals were randomly divided into two groups of five goats each i.e. the control and the experimental group. The wound of the experimental group was dressed daily with $0.035 \mathrm{ppm}$ solution of lead chloride. Blood lead at this level caused clinical symptoms of excessive perspiration at rest and headache (Elegbede et al., 2012). The control group was also dressed daily with $0.9 \%$ normal saline. The wounds were covered with moist saline dressing to safe guard it and the experiment lasted for nine days when control animal wound healed completely.

Wound creation: The operation site (lateral to the thoracic vertebrae and lying to the proximal body of the rib)was clipped, washed with soap and water and shaved. Ethanol (70\%) was applied as an antiseptic for the shaved region before the wound creation and the animal was placed on the operation table on left lateral recumbency. Infiltration anaesthesia was performed using $2 \%$ lignocaine hydrochloride at the back of the animals i.e. the dorsum in the thoracic and lumbar region of each of the animals. The dimension of the epidermal wound created was $1 \mathrm{~cm}^{2}$. The progressive changes in the wound contraction were monitored grossly by placing clean and sterile veniercaliper on the wound margins. The length and breadth were also measured to determine the wound surface area. This method was according to previous work (Olaifa et al., 2016).This experiment was carried out in accordance with the ethical committee of the university of Ibadan ethical rules on animal experiment with approval number UIACUREC/App/2016/019. Hematology and serum biochemical studies Blood was collected on days $0,3,6$ and 9 through the jugular vein, into an anti-coagulant free sample bottle and allowed to coagulate at room temperature $(270 \mathrm{C})$ with the bottle slanted to obtain the serum.

The serum total protein was determined by the Biuret method (Reinhold, 1953), while albumin value was obtained by bromocresol green method (Doumas and Biggs, 1971). Globulin was obtained from the difference of total protein and albumin. Serum urea and Creatinine levels was determined using photoelectric colorimeter (Coles, 1989). Aspartate aminotransferase (AST) and alanine aminotransferase (ALT) activities were measured using a colorimetric method (Reitman and Frankel 1957). The blood samples collected for haematology were evaluated for packed cell volume (PCV) through the haematocrit method (Jain and Schalm, 1986). Haemoglobin concentration was evaluated using the cyanomethaemoglobin method (Schalm et al., 1975). Red blood cell count was determined by the haematocytometry method (Jain and Schalm, 1986). Total white blood cell (WBC) counts and differential leucocyte counts were made according to Coles (1989). Haematometric indices including Mean Corpuscular Volume (MCV) and Mean Corpuscular Haemoglobin $(\mathrm{MCH})$ were determined from the values obtained from red blood cell count, haemoglobin level and PCV values (Duncan et al., 1994).

\section{Data analysis}

Data collected were subjected to statistical analysis using the student's t-test, values of $\mathrm{P}<0.05$ were considered statistical significant and were presented as Mean \pm standard error of mean.

\section{RESULTS}

WAD goats subjected to lead chloride administration through the wound revealed marked delayed in wound contraction (Table 1), marked decrease in PCV, Hb, ESR, albumin (Table 2 and 3 ) and a significant increase in heart rate and temperature. Creatinine, BUN, globulin, glucose, and total protein did not show any significant changes.

\section{DISCUSSION}

Wound healing is a complex and dynamic process, with the wound environment changing with the shifting healt 
Table 1: Wound Contraction rate $(\mathrm{cm} 2)$ of control and lead chloride treated goats.

\begin{tabular}{ccc}
\hline Day & Control & Lead-treated \\
\hline 0 & $100.00 \pm 0.00$ & $100.00 \pm 0.00$ \\
3 & $59.53 \pm 2.66$ & $68.35 \pm 3.18$ \\
6 & $0.00 \pm 0.00$ & $23.74 \pm 8.98^{*}$ \\
9 & $0.00 \pm 0.00$ & $12.95 \pm 8.72$ \\
\hline
\end{tabular}

${ }^{*} P<0.05$, values are Mean \pm SEM

Table 2: Effect of wound lead poisoning on Hematological indices

\begin{tabular}{|c|c|c|c|}
\hline Haematological indices & Day & Control & Lead-treated \\
\hline \multirow[t]{4}{*}{ ESR } & 0 & $2.80 \pm 0.58$ & $1.80 \pm 0.37$ \\
\hline & 3 & $2.60 \pm 0.81$ & $2.40 \pm 0.51$ \\
\hline & 6 & $2.00 \pm 0.32$ & $1.00 \pm 0.00 *$ \\
\hline & 9 & $1.60 \pm 0.24$ & $1.80 \pm 0.37$ \\
\hline \multirow[t]{4}{*}{$\mathrm{Hb}(\mathrm{g} / \mathrm{l})$} & 0 & $13.10 \pm 1.67$ & $13.12 \pm 1.29$ \\
\hline & 3 & $11.04 \pm 1.24$ & $10.22 \pm 0.94$ \\
\hline & 6 & $10.60 \pm 1.13$ & $7.72 \pm 0.56$ \\
\hline & 9 & $10.32 \pm 1.64$ & $7.02 \pm 1.04^{*}$ \\
\hline \multirow[t]{4}{*}{ PCV (\%) } & 0 & $40.60 \pm 4.18$ & $43.60 \pm 4.70$ \\
\hline & 3 & $34.00 \pm 3.26$ & $30.80 \pm 2.84$ \\
\hline & 6 & $32.00 \pm 3.42$ & $24.60 \pm 1.86$ \\
\hline & 9 & $31.20 \pm 4.90$ & $21.20 \pm 3.18^{*}$ \\
\hline \multirow[t]{4}{*}{$\operatorname{RBC}\left(\times 10^{12} / \mathrm{I}\right)$} & 0 & $10.77 \pm 0.59$ & $11.54 \pm 1.03$ \\
\hline & 3 & $13.79 \pm 1.56$ & $17.03 \pm 1.74$ \\
\hline & 6 & $20.10 \pm 1.62$ & $19.97 \pm 1.55$ \\
\hline & 9 & $15.97 \pm 2.08$ & $21.39 \pm 3.08$ \\
\hline \multirow[t]{4}{*}{$\mathrm{MCH}(p g)$} & 0 & $11.80 \pm 1.07$ & $13.20 \pm 2.54$ \\
\hline & 3 & $6.80 \pm 0.58$ & $6.20 \pm 0.66$ \\
\hline & 6 & $3.40 \pm 0.51$ & $5.00 \pm 0.45$ \\
\hline & 9 & $3.40 \pm 0.51$ & $5.00 \pm 0.45$ \\
\hline \multirow[t]{4}{*}{$\operatorname{MCV}(\mathrm{fl})$} & 0 & $40.40 \pm 4.18$ & $34.80 \pm 2.42$ \\
\hline & 3 & $22.00 \pm 1.55$ & $19.60 \pm 1.78$ \\
\hline & 6 & $12.00 \pm 1.58$ & $15.60 \pm 1.69$ \\
\hline & 9 & $12.00 \pm 1.58$ & $15.60 \pm 1.69$ \\
\hline \multirow[t]{4}{*}{ WBC $\left(\times 10^{9} / I\right)$} & 0 & $8.32 \pm 1.25$ & $9.48 \pm 0.49$ \\
\hline & 3 & $7.20 \pm 0.75$ & $10.12 \pm 0.77$ \\
\hline & 6 & $12.96 \pm 1.25$ & $12.40 \pm 2.11$ \\
\hline & 9 & $10.88 \pm 1.30$ & $13.96 \pm 3.72$ \\
\hline \multirow[t]{3}{*}{ Neutrophils $\left(\times 10^{9} / \mathrm{I}\right)$} & 0 & $36.40 \pm 2.71$ & $30.00 \pm 2.66$ \\
\hline & 3 & $38.20 \pm 1.28$ & $42.20 \pm 1.46$ \\
\hline & 6 & $38.80 \pm 1.39$ & $42.60 \pm 2.50$ \\
\hline
\end{tabular}


Table 2 cont.

\begin{tabular}{|c|c|c|c|}
\hline & 9 & $36.40 \pm 2.62$ & $32.80 \pm 3.28^{*}$ \\
\hline \multirow[t]{3}{*}{ Lymphocyte (x10/l) } & $\begin{array}{l}0 \\
3\end{array}$ & $\begin{array}{l}63.40 \pm 2.54 \\
61.20 \pm 1.46\end{array}$ & $\begin{array}{l}70.00 \pm 2.66 \\
57.20 \pm 1.59\end{array}$ \\
\hline & 6 & $60.40 \pm 1.40$ & $56.80 \pm 2.31$ \\
\hline & 9 & $62.40 \pm 2.66$ & $65.80 \pm 3.10$ \\
\hline \multirow[t]{3}{*}{ Platelets $\left(x 10^{9} / \mathrm{l}\right)$} & $\begin{array}{l}0 \\
3\end{array}$ & $\begin{array}{l}14.00 \pm 1.26 \\
10.00 \pm 1.41\end{array}$ & $\begin{array}{l}13.60 \pm 1.33 \\
11.00 \pm 1.48\end{array}$ \\
\hline & 6 & $8.40 \pm 1.17$ & $11.20 \pm 1.36$ \\
\hline & 9 & $7.60 \pm 1.44$ & $10.60 \pm 1.54$ \\
\hline
\end{tabular}

${ }^{*} P<0.05$, values are Mean $\pm S E M$

Table 3: Effect of wound lead poisoning on serum biochemical parameters

\begin{tabular}{|c|c|c|c|}
\hline Biochemical Parameters & Days & Control & Lead-treated \\
\hline \multirow[t]{4}{*}{ Albumin (mg/dl) } & 0 & $1.14 \pm 0.04$ & $1.46 \pm 0.21$ \\
\hline & 3 & $1.12 \pm 0.06$ & $1.28 \pm 0.19$ \\
\hline & 6 & $1.24 \pm 0.07$ & $1.12 \pm 0.04^{*}$ \\
\hline & 9 & $1.06 \pm 0.04$ & $1.34 \pm 0.22$ \\
\hline \multirow[t]{4}{*}{ ALT } & 0 & $42.20 \pm 3.20$ & $42.40 \pm 9.19$ \\
\hline & 3 & $38.60 \pm 2.89$ & $40.00 \pm 8.06$ \\
\hline & 6 & $37.60 \pm 2.32$ & $37.80 \pm 7.44$ \\
\hline & 9 & $29.80 \pm 7.89$ & $40.00 \pm 12.08$ \\
\hline \multirow[t]{4}{*}{ AST } & 0 & $10.00 \pm 0.63$ & $10.80 \pm 1.96$ \\
\hline & 3 & $8.00 \pm 0.63$ & $8.60 \pm 1.94$ \\
\hline & 6 & $6.60 \pm 0.60$ & $10.20 \pm 1.28^{*}$ \\
\hline & 9 & $5.00 \pm 1.41$ & $9.00 \pm 3.00$ \\
\hline \multirow[t]{4}{*}{ BUN } & 0 & $1.07 \pm 0.03$ & $1.25 \pm 0.25$ \\
\hline & 3 & $1.02 \pm 0.02$ & $1.26 \pm 0.24$ \\
\hline & 6 & $1.02 \pm 0.02$ & $1.29 \pm 0.21$ \\
\hline & 9 & $1.06 \pm 0.04$ & $1.50 \pm 0.31$ \\
\hline \multirow[t]{4}{*}{ Creatinine } & 0 & $1.18 \pm 0.08$ & $1.26 \pm 0.24$ \\
\hline & 3 & $1.10 \pm 0.04$ & $1.22 \pm 0.22$ \\
\hline & 6 & $1.10 \pm 0.03$ & $1.26 \pm 0.19$ \\
\hline & 9 & $1.06 \pm 0.04$ & $1.30 \pm 0.19$ \\
\hline \multirow[t]{4}{*}{ Globulin (mg/dl) } & 0 & $2.54 \pm 0.28$ & $2.34 \pm 0.26$ \\
\hline & 3 & $2.26 \pm 0.28$ & $2.04 \pm 0.35$ \\
\hline & 6 & $1.92 \pm 0.20$ & $2.34 \pm 0.14$ \\
\hline & 9 & $2.06 \pm 0.15$ & $2.36 \pm 0.32$ \\
\hline
\end{tabular}


Table 3 Cont.

\begin{tabular}{llcc}
\hline Glucose (mg/dl) & 0 & $51.20 \pm 3.01$ & $53.20 \pm 5.07$ \\
& 3 & $47.80 \pm 3.35$ & $46.60 \pm 5.88$ \\
Total Protein (mg/dl) & 6 & $43.40 \pm 3.89$ & $44.60 \pm 5.53$ \\
& 9 & $35.80 \pm 7.28$ & $44.20 \pm 9.22$ \\
& 0 & $3.68 \pm 0.29$ & $3.82 \pm 0.43$ \\
& 3 & $3.38 \pm 0.32$ & $3.34 \pm 0.50$ \\
& 6 & $3.16 \pm 0.26$ & $3.46 \pm 0.18$ \\
& 9 & $3.12 \pm 0.18$ & $3.70 \pm 0.49$ \\
\hline
\end{tabular}

${ }^{\star} P<0.05$, values are Mean \pm SEM

status of an individual. Among the heavy metals, lead still remains the major toxic pollutant of the environment which occurs through air, food, dust and water. Lead intoxication through wound could be an environmental and local factor that impairs wound healing in animals.

The result of this study shows a significant delay in wound healing of the lead-treated goats. Exposure to lead has been shown to increase production of reactive oxygen species (ROS) and consequently induce lipid peroxidation and alteration of antioxidant defense systems in mice (Demirezen and Kadiriye, 2006), rats (Haleagrahara et al., 2011)and goat (Mousa et al., 2002)resulting in oxidative stress (Xienia et al., 2000). The pathophysiology of stress results in the deregulation of the immune system, mediated primarily through the hypothalamic-pituitary adrenal (HPA) and sympatheticadrenal medullary axes or sympathetic nervous system (Boyapati and Wang, 2007). Studies in both humans and animals have demonstrated that stress causes a substantial delay in wound healing (Broadbent et al., 2003; Lisa et al., 2006). The hypothalamic-pituitaryadrenal and the sympathetic- adrenal medullary axes regulate the release of pituitary and adrenal hormones. These hormones include the adrenocorticotrophic hormones, cortisol, and catecholamines (epinephrine and norepinephrine). Stress up-regulates glucocorticoids (GCs) and reduces the levels of the proinflammatory cytokines IL-1 $\beta$, IL- 6 , and TNF- $\alpha$ at the wound site. Stress also reduces the expression of IL- $1 \alpha$ and IL- 8 at wound sites-both chemo attractants that are necessary for the initial inflammatory phase of wound healing (Boyapati and Wang, 2007).

Furthermore, GCs influence immune cells by suppressing differentiation and proliferation, regulating gene transcription, and reducing expression of cell adhesion molecules that are involved in immune cell trafficking (Sternberg, 2006). The result indicated a significant reduction $(\mathrm{P}<0.05)$ in haemoglobin $(\mathrm{Hb})$, packed cell volume (PCV) and erythrocyte sedimentation rate (ESR) in lead-treated goat compared to the control group. This haematological alteration might be due to effect of lead on activity of $\alpha$ aminolevulinic acid dehydratase (ALAD), key enzyme of heme synthesis. Moreover lead also inhibit the conversion of coproporphyrinogen III to protoporphyrin IX leading to reduction in haemoglobin production, shortened life span of erythrocytes and interacts with some reactions where calcium is their secondary mediator (Klassen, 2001). This corroborates earlier studies (Mugahi et al., 2003; Sujatha et al., 2011) and show microcytic hypochromic anemia (Suradkar et al., 2009; Alwaleedi, 2015). Progressive destruction of RBCs due to binding of lead with RBCs, leading to increase fragility and destruction and generation of reactive oxygen results from interference of lead in heme synthesis through inhibition of 5-aminolevulinic acid dehydratase activity resulting in increased production of 5 -aminolevulinic acid (Moore,

1986; Adonaylo and Oteiza, 1999).; could be another reason for decrease haematological values (Rous, 2000).Platelets count revealed considerable insignificant increase in lead-treated animals compared to the control. This may be due to thrombocytopenia and thrombocytosis after chronic lead intoxication (Sudakova et al., 1983; Mugahi et al., 2003; Abdulkareem, 2010); while the insignificant increase in the white blood cell may be due to lead induced inflammation (Yagminas et al., 1990, Alwaleedi, 2015).Significant increase in ALT and AST which are biomarkers for liver toxicity was observed in this study $(\mathrm{P}<0.05)$, might be due to increased cell membrane permeability, increased cellular basal metabolic rate or cell membrane damage of hepatocytes caused by lead acetate. These results agree with previous studies reported an elevation in AST and ALT levels after treatment with lead due to acute hepatitis, jaundice, and liver cirrhosis in mice, human and rat(Mehta et al., 2002; Patil et al., 2007; Shalan et al., 2005, Alwaleedi, 2015), also in sheep (Badiei et al., 2009). The significant decrease in albumin at the reparatory phase 
might be due to binding of lead to albumin (Stone and Soares, 1976), disturbance in the protein metabolism in the liver consequent to accumulation of lead leads to liver injury(Sharaf et al., 2008). Patil et al., 2007,Dongre et al., 2010 and Kshirsagar et al., 2015 also reported a decrease in the synthesis of albumin and other protein as a result of increased blood lead level. However, creatinine, BUN, globulin and glucose did not show any significant change which might be due to the homeostasis processes set in by the body in response to wound lead contamination. The result also showed a significant $(P<0.05)$ increased in heart rate of lead-treated animals as compared to the control group. This agrees with Park et al.,(2008) that reported that people with long-term exposure to higher levels of lead may be more sensitive to cardiac autonomic dysfunction and heart rate variability. Also, Lead exposure effects like increasing the generation of reactive oxygen species by depletion of glutathione and protein-bound sulfhydryl groups, leading to oxidative stress (Gurer and Ercal, 2000); induces irondependent lipid peroxidation in liposomal membranes (Adonaylo, 1999); down-regulating of nitric oxide generation (Vaziri, 2002); inhibiting the intracellular calcium messenger system and altering calcium homeostasis because of its mimicry of the calcium ion (Sandhir and Gill, 1994). All these effects are associated with sympathetic excitation and vagal withdrawal (Ding et al., 2000; Dursun et al., 2005).

In conclusion, epidermal wound lead contamination markedly delayed wound contraction and healing, reduced haematological parametersandhepato-toxicity. Therefore, lead contamination in animals either orally in food and water or epidermally should be avoided.

\section{References}

Abdulkareem A. (2010). Thrombocytosis secondary to chronic lead poisoning.Platelets; 21(4):297-299

Adonaylo VN, Oteiza PI (1999a). Lead intoxication: antioxidant defenses and oxidativedamage in rat brain. Toxicology 135: 77-85.

Adonaylo VN, Oteiza PI (1999b). Pb2+ promotes lipid oxidation and alterations in membranephysical properties. Toxicology 132:19-32.

Agency for Toxic Substances and Disease Registry (ATSDR, 2005).Toxicological profile for lead, Atlanta: US Department of Health and Human Services, Public Health Service.

AlwaleediSA (2015). Haemato-Biochemical Changes Induced by Lead Intoxication in Male andFemale Albino Mice. International Journal of Recent Scientific Research 6 (5), 3999-4004

Andrews KW, Savitz DA, Hertz-Picciotto I (1994). Prenatal lead exposure in relation togestational age and birth weight: $A$ review of epidemiologic studies.American Journal of Industrial Medicine 26(1): 13-32.

Badiei, K, Nikghadam P, Mostaghni K,Zarifi M (2009). Effect of lead on thyroid function in sheep.Iranian J. Vet. Res. Shiraz University; 10 (3): 223-227

Bellinger DC. 2008. Very low lead exposures and children's neurodevelopment. Current opinion in pediatrics 20(2): 172-177.

Boyapati L, Wang HL (2007). The role of stress in periodontal disease and wound healing.Periodontol 2000; 44:195-210.

Broadbent E, Petrie KJ, Alley PG, Booth RJ (2003). Psychological stress impairs wound repairfollowing surgery. Psychosom Med; 65: 865-869.
Brownie CF, Brownie C, Lopez V, Cadogan P (2009). Dogs and goats as sentinels forenvironmental lead burden in Caribbean basin islands: Jamaica West Indies. West Indian Veterinary Journal, 9 (2) 17-20

Coles EH (1989). Veterinary Clinical Pathology, 4th edition (W.B. Saunders Co., USA, 1989).

Demirezen D, Kadiriye, U (2006). Comparative study of trace elements in certain fish, meat and meat production.Meat Sci 74 , 255-260.

Dietert RR, Piepenbrink MS (2006).Lead and immune function.Crit Rev Toxicol 36(4): 359-385.

Ding Y, Gonick HC, Vaziri ND (2000). Lead promotes hydroxyl radical generation and lipidperoxidation in cultured aortic endothelial cells. Am J Hypertens. 13(5 pt 1):552-555.

Dongre NN, Suryakar AN, Patil AJ, Rathi DB (2010).Occupational Lead Exposure inAutomobile Workers in North Karnataka (India): Effect on Liver and Kidney Functions. Al Ameen J Med Sci; 3(4):284-292.

Doumas BT, Biggs HG (1971). Determination of serum albumin In: Standard methods of clinical chemistry GR. Cooper (ed). Academy press, New York. pp. 7-175.

Duncan J.R., Prasse K.W ., Mahaffey E.A (1994). Veterinary Laboratory Medicine. lowa State University press, USA

Dursun N, Arifoglu C, Suer C (2005). Blood pressure relationship to nitric oxide, lipid peroxidation, renal function, and renal blood flow in rats exposed to low lead levels. Biol Trace Elem Res.; 104:141149.

Elegebede B, Edorh PA, Aissi AK, Koumolou L, Kaki C (2012). Blood lead levels and Biomarkers of Lead Toxicity via the Consumption of Drinking water in Kerou (Benin) in Watershed of the Niger. IJEP; 2 (6): $10-15$

Gurer $\mathrm{H}$, Ercal N (2000). Can antioxidants be beneficial in the treatment of lead poisoning? Free Radic Biol Med.; 29:927-94573.

Haleagrahara N, Chakravarthi S, Kulur AB. Radhakrishnan A (2011). Effects of chronic lead acetate exposure on bone marrow lipid peroxidation and antioxidant enzyme activities inrats.Afr. J. Pharm. Pharmacol. 5(7), 923-929.

Jain NC, Schalm(1986). Veterinary Haematology, 4th edn. (Lea and Febiger, USA)

Klassen CD (2001). Casarett and Doull's Toxicology: The basic Science of poisons. 6th edn.McGraw-Hill Medical publishing division.pp 812-841.

Kshirsagar M, Patil J, Patil A, Ghanwat G, Sontakke A, Ayachit R.K. (2015). Biochemical effects of lead exposure and toxicity on battery manufacturing workers of Western Maharashtra (India): with respect to liver and kidney function tests. Al Ameen J Med Sci; 8(2):107-114.

Lisa MC, Jennifer EG, David AP, Ronald G, Kiecolt-Glaser J. (2006). Stress and Wound healing. Neuroimmunomodulation13: 337-346

Mathieu D, Linke J-C, Wattel F (2006). Non-healing wounds. In: Handbook on hyperbaric medicine, Mathieu DE, editor. Netherlands: Springer, pp.401-427.

Mehta A, Kajnnan GM, Dube SN, Pant BP, Pant SC, Flora SJS (2002). Hematological, hepatic and renal alterations after repeated oral or intraperitoneal administration of monoisoamyl DMSA. I. Changes in male mice. J Apple Toxicol22, 359- 369.

Moore M R(1986). Lead intoxication. Semin.Dermato.5, 69-177

Mousa HM, Al-Qarawi AA, Ali BH, Abdel Rahman HA and SA EIMougy (2002).Effect of Lead Exposure on the Erythrocytic Antioxidant Levels in Goats.J. Vet. Med. A 49, 531-534

Mugahi, M.N., Heidari, Z., Sagheb, H.M., and Barbarestani, M. (2003). Effects of chronic leadacetate intoxication on blood indices of male adult rat.DARU 11, 147-151.

Navas-Acien A, Guallar E, Silbergeld E.K, Rothenberg S.J. (2007). Lead exposure and cardiovascular disease--a systematic review. Environ Health Perspect115(3): 472-482.

Odunsi AA, Togun VA, Oladunyoye IO (2005). Introduction to Animal Production and Processing.Oluseyi Press Limited, Nigeria.

Okunlola JO (2000). Socio-economic constraint in sheep and goat production in Ekiti and Ondo State.M.Sc Thesis, University of Ibadan, lbadan, Nigeria. 
Olaifa AK., Samuel OO, Banjoko OM (2016) Effects of Topical $17 \beta$ Estradiol on Wound Healing and Hemato-Biochemical Changes In West African Dwarf Goats. International Journal of Livestock Research, 6 (8), 15-26.

Pain D, Fisher IJ, Thomas VG (2009).A Global Update of Lead Poisoning in Terrestrial Birds fromAmmunition Sources. In: Watson RT, Fuller M, Pokras M, Hunt WG, editors. Ingestion of Lead from Spent Ammunition: Implications for Wildlife and Humans. The Peregrine Fund; p. 99-118.

Patra RC,Swarup D(2000). Effect of lead on erythrocytic antioxidant defense, lipid peroxidelevel and thiol groups in calves. Research of Veterinary Science, 68: 71-74.

Patil AJ, Bhagwat VR, Patil JA, Dongre NN, Ambekar JG, Das KK (2007). Occupational lead exposure in battery manufacturing workers, silver jewelry workers, and spray painters inWestern Maharashtra (India): effect on liver and kidney function. J. Basic Clin. Physiol. Pharmacol. 2007; 18(2):87-100.

Radostits OM, Gray CC, Blood DC, Hinchcliff KW (2000). Veterinary medicine. 9th Ed., W .B Saunders Co., P: 1575

Reinhold JG (1953). Standard Methods of Clinical Chemistry. Academic Press, New York.

Reitman AG, Frankel S (1957). A colorimetric method for the determination of serum glutamic transaoxalecetic and glutamic pyruvic transaminases. American Journal of Clinical Pathology 28: 56-63.

Rous $P$ (2000). The effect of heavy metals boundary contaminated soil on haematological and selected biochemical parameters in blood plasma of rabbits. Acta-Universitatis-Agriculturae-et-Silviculturae-MendelianaeBrunensis 48, 93-99.

Sandhir R, Gill KD(1994) Alterations in calcium homeostasis on lead exposure in rat synaptosomes. Mol Cell Biochem; 131:25-33

Schalm OW, Jain NC and Carrol E (1975). Veterinary Haematology 3rd Edition Lea and Febiger, Philadephia USA, 160-21

Seyoum S (2002). Economic of small ruminant meat production and consumption in Sub-SaharanAfrica. International Livestock Centre for Africa, 2: $15-26$.

Siddiqui M F, Rajurkar GR (2008) Lead - An Emerging threat to livestock Veterinary World,Vol.1 (7): 213-216

Shalan, MG, Mostafa MS, Hasouna MM, Nabi SE Refaie A (2005).Amelioration of lead toxicity on rat liver with vitamin $C$ and silymarin supplements. Toxicology 206, 1-15.

Sharaf, NE Zaki, MS Gomaa WR Batrawy NEI, Fawzi, OM (2008). Some Clinicopathological and microbiological studies on lead toxicity in bull. American Eurasian Journal of Agricultural and Environmental Science, 3(2): 165-168.

Sternberg EM (2006). Neural regulation of innate immunity: a coordinated nonspecific hostresponse to pathogens. Nat Rev Immunol6:318-328.

Stone CL, Soares JH (1976). The effect of dietary selenium level on lead toxicity in the Japanese quail.Poultry Science 55: 341-349.

Sudakova AI, Shevchenko ZT, Nosova LI (1983). Peripheral blood and bone marrow cell status of white rats with long-term lead exposure. Tsitol Genet 17, 3-7.

Sujatha KK, Sri lathach, Anjaneyulu Y, Chandra S, Rao TS, SreeniVasulu D, Amravathi PP (2011). Hematobiochemical changes of lead Poisoning and amelioration with Ocimum sanctum in wistar albino rats. Veterinary World, 4(6): 260-263

Suradkar SG, Ghodasara DJ, Patel J, Jaiswal V, Prajapati KS (2009). Haemato-Biochemical alterations induced by lead acetate toxicity in wistar rats. Vet World; 2, 429-431.

Vaziri ND(2002) Pathogenesis of lead-induced hypertension: role of oxidative stress.J Hypertens,20 (3):S15-S20

Weaver VM, Griswold M, Todd AC, Jaar BG, Ahn KD, Thompson CB (2009). Longitudinal associations between lead dose and renal function in lead workers. Environ Res 109(1):101-107.

Weisskopf MG, Wright RO, Schwartz J, Spiro A, Sparrow D, Aro A (2004). Cumulative lead exposure and prospective change in cognition among elderly men: the VA Normative Aging Study. Am J Epidemiol 160(12): 1184-1193.
Xienia U, Foote GC, Van S, Devreotes PN, Alexander S, Alexander H (2000).Differential developmental expression and cell type specificity of Dictyostelium catalasesand their response to oxidative stress and UV light. BiochimBiophysActa 1492, 295- 310.

Yagminas AP, Franklin CA, Villeneuve DC, Gilman AP, Little PB, Valli VE (1990).Subchronic oral toxicity of triethyllead in the male weanling rat. Clinical, biochemical, hematological, and histopathological effects Fundam. Appl. 15,580-596 